Nor has an unquestionable proof of the relation of nerve-cell changes to the clinical picture called shock, yet been advanced. Local anesthesia to date has eliminated shock from those operations which can be done under its influence. In the larger operations, however, except those about the neck for carcinoma and in carcinoma of the rectum, it has not, as yet, been fully successful. In many operations, by reducing the period of anesthesia, it has reduced the tax on the patient's resistance. In the grave abdominal operations it has, so far, contributed but little. The visceral nerves, when irritated by inflammation or by the invasion of new growths, are exceedingly sensitive, and no safe method has yet been devised to prevent the transmission of these impulses to the brain. In these cases all that local anesthesia can do is to make the abdominal wall insensitive, and it seems likely that this is but a small factor in the production of shock. The prevention of shock in these cases must depend on the deftness of the operator, and his ability to judge conditions correctly in order that he may manage them with the least traumatism, in the shortest time, with the least loss of blood.

Rialto Building.

\section{DISCOVERY OF BACTERIUM TULARENSE IN WILD RABBITS AND THE DANGER OF ITS TRANSFER TO MAN}

PRELIMINARY NOTE*

WILLIAM B. WHERRY, M.D. AND

B. H. LAMB

CINCINNATI

We wish to record our recent demonstration of Bacterium tularcnse in a fatal epizootic among wild rabbits, and to emphasize again the fact that this disease is probably widely distributed among rodents and probably transferred to man more frequently than heretofore recorded. We have demonstrated this virus in two severe cases of conjunctivitis accompanied by lymphadenitis, high fever and marked prostration. The first case of human infection has already been reported by us. ${ }^{1}$ This case came under the care of 1.)r. Derrick 'T. Vail ${ }^{2}$ of Cincinnati, who has reported the details of the clinical course of this casc. The sccond case is still under the care of Dr. Robert Sattler of Cincinnati, and will be reported by him.

McCoy and Chapin first described the disease in the California ground squirrel. Naturally we have been anxious to find the source of human infection in this locality. Through the kindly cooperation of Dr. J. H. Iandis, Heaith Officer of Cincinnati, we have been able to do so. Dr. Landis heard that rabbits were dying in large numbers in the neighborhood of Vevay, Ind. (Switzerland County). Two men were sent down, November 12, to investigate the rumor. They could not find any evidence of extensive mortality among rabbits, but they shot three and found two dead on the M. farm about 6 miles from Vevay. These were dissected, November 13, and both of those found dead were proved to be infected with $B$. tularense.

* From the Laboratory of the Cincinnati Hospital.

1. Wherry, W. B., and Lamb, B. H.: Jour. Infect. Dis., 1914, $\mathrm{xv}, 331$.

2. Vail, D. T.: Ophth. Rec., October, 1914.
RABBiт 1.-The external appearances were normal, excepting for the presence of many fly larvae in the nose and mouth and on the skin. None of these had penetrated the tissues, so it is presumable that the rabbit was found soon after it died. On dissection the subcutaneous tissues showed some injection.

There were many small irregular areas of hemorrhage into the skin covering the posterior aspect of the hind legs and rumps. The cervical glands were congested and firm on section. The spleen was a deep blue-black and about four times the normal size and speckled all over with minute whitish foci of necrosis. The liver was congested and also showed numerous foci of necrosis. The lungs appeared normal excepting for a few patchy areas of consolidation of a deep brownish-red. The peritoneal cavity was full of a hemoglobin-tinged serous exudate.

Smears from the spleen stained with anilin (Hoffman's violet) showed numerous irregular, coccoid, encapsulated bodies resembling the involution forms of $B$. tularense.

Guinea-Pig 1 inoculated subcutaneously with an emulsion of the spleen of Rabbit 1 was chloroformed when dying on the third day thereafter. It showed the typical lesions which have been described by McCoy and Chapin, and by us. B. tularcnse was isolated from the spleen of this guinea-pig on a slant of coagulated egg-yolk, while no growth appeared on control slants of plain nutrient agar and rabbit's blood agar.

RABBIT 2.-This animal showed marked post-mortem decomposition and was badly fly-blown. However, minute whitish foci of necrosis could be made out on the soft enlarged spleen and on the liver. An enlarged axillary gland was emulsified and injected subcutaneously into Guinea-Pig 3. This pig died in three and a half days, showing the typical lesions of infection with $B$. tularense.

We are anxious to help physicians in the discovery of further cases in man. It may be that physicians in country districts who have not the facilities for bacteriologic study may be willing to send us material from severe cases of conjunctivitis or lymphadenitis in man. These may well prove to be cases of this disease when there is a history of having shot or handled rabbits,' squirrels or ground squirrels. A cotton swab, soaked in such exudations as can be reached, mailed to us by special delivery and accompanied by a note concerning the nature of the case will be reported on as soon as possible.

Conservation in Evolution.-Organisms have evolved by a trial and error method; they experiment organically, instinctively, and intelligently; above all, perhaps, in the mysterious antenatal life of the germ cells they experiment in selfexpression-just as water vapour does in snowflakes, but far more subtly. What are called variations and mutations in biological language are the organism's experiments in selfexpression, and these are the raw materials of progress. The organism proves all things, but the other side is that it holds fast that which is good. Great gains once made are not held lightly. Species become extinct and races perish, but important organic inventions are carried on by some collateral lineage. It was probably some ribbon worm that first manufactured hemoglobin-the all-important red pigment of the blood. Many backboneless animals of higher degree on different lines of evolution have not got it, but the invention was too good to lose; and everyone knows that it was retained on collateral lines, and that all backboned animals from fishes onward have red blood. Or again, the most primitive and in a way most puzzling kind of locomotion is that of the ameba gliding in the pond. Is it not a most suggestive fact that our health from day to day and the development of our nervous system are absolutely dependent on this self-same ameboid movement?-J. Arthur Thomson, Brit. Med. Jour. 